\title{
An antimicrobial peptide specifically active against Listeria monocytogenes is secreted by Bacillus pumilus SF214
}

\author{
Anella Saggese ${ }^{1}\left(\mathbb{D}\right.$, Ylenia De Luca ${ }^{1}$, Loredana Baccigalupi ${ }^{2}$ (D) and Ezio Ricca ${ }^{1 *}$ (D)
}

\begin{abstract}
Background: Members of the Bacillus genus produce a large variety of antimicrobial peptides including linear or cyclic lipopeptides and thiopeptides, that often have a broad spectrum of action against Gram-positive and Gramnegative bacteria. We have recently reported that SF214, a marine isolated strain of Bacillus pumilus, produces two different antimicrobials specifically active against either Staphylococcus aureus or Listeria monocytogenes. The antiStaphylococcus molecule has been previously characterized as a pumilacidin, a nonribosomally synthesized lipopetide composed of a mixture of cyclic heptapeptides linked to fatty acids of variable length.

Results: Our analysis on the anti-Listeria molecule of B. pumilus SF214 indicated that it is a peptide slightly smaller than $10 \mathrm{kDa}$, produced during the exponential phase of growth, stable at a wide range of $\mathrm{pH}$ conditions and resistant to various chemical treatments. The peptide showed a lytic activity against growing but not resting cells of $L$ isteria monocytogenes and appeared extremely specific being inactive also against $L$. innocua, a close relative of $L$. monocytogenes.
\end{abstract}

Conclusions: These findings indicate that the B. pumilus peptide is unusual with respect to other antimicrobials both for its time of synthesis and secretion and for its strict specificity against L. monocytogenes. Such specificity, together with its stability, propose this new antimicrobial as a tool for potential biotechnological applications in the fight against the dangerous food-borne pathogen L. monocytogenes.

Keywords: Bacillus, Antimicrobials, AMP, anti-Listeria, Lytic peptide, Membrane damages

\section{Background}

Antibiotic resistance is a major threat to global health and is predicted to cause by 2050 millions of annual deaths [1]. In addition to an increased incidence of infectious diseases, the lack of effective antibiotics will certainly affect many surgical procedures and treatments that suppress the immune system (for example, chemotherapies) [1]. Therefore, the identification of new strategies to fight the continuous rise of resistant pathogens is

\footnotetext{
*Correspondence: ericca@unina.it

${ }^{1}$ Department of Biology, Federico II University, via Cinthia, Complesso

Universitario di Monte Sant'Angelo, 80126 Naples, Italy

Full list of author information is available at the end of the article
}

an enormous challenge for the scientific community [1, 2]. So far, alternatives to antibiotics such as vaccines and probiotics, have been proposed together with the identification and design of new antibiotics.

In this context, antimicrobial peptides (AMPs) have gained great attention as new antibiotics. They have been characterized from almost every organism of all domains of life and shown to play an important role in innate immunity, protecting the producing organisms from infections [1]. Many AMPs act on membrane lipids and show a broad-spectrum of action against Gram-positive and Gram-negative bacteria, some AMPs are active against fungi, viruses or other parasites [1]. AMPs from vertebrates (defensins and cathelicidins), in addition to 
the antimicrobial activity, also act as chemo-attractants, are involved in the activation of complement pathways and are able to modulate the immune response [1]. Over 3,000 AMPs, showing an extraordinary chemical diversity and isolated from a variety of biological sources, have been described and are collected in specific databases (see for example: http://aps.unmc.edu/AP/main.php; https://wangapd3.com/main.php; https://dbaasp.org/).

Bacteria and fungi in particular have been investigated as a source of new AMPs, and although most microorganisms produce AMPs, bacteria of the Bacillus genus have received deep attention as potential starting points in the search for new inhibitory substances [2]. These rod-shaped, endospore-forming, Gram-positive bacteria are common in many natural habitats and produce a variety of AMPs: short linear or cyclic peptides of up to 30 amino acid residues; lipopeptides containing a hydrocarbon tail linked to the $\mathrm{N}$-terminus of the linear or cyclic peptide; thiopeptides, sulphur-rich peptides with thiazole, oxazole, or thiazoline rings; and 2,5-diketopiperazines (DKPs), extremely small peptides (even di-amino acids) with structural modifications [2,3].

The best known AMPs produced by Bacilli are cyclic lipopeptides of three structural categories: surfactins, iturins and fengycins. In addition, tens of linear or cyclic lipopeptides not belonging to those three classes, have been identified and extensively reviewed by Zhao et al. [2] and Cauller et al. [3].

In Bacilli AMPs biosynthesis principally occurs by two different biosynthetic pathways: the non-ribosomal synthesis of peptides by large mega-enzymes, the nonribosomal peptide synthetases (NRPSs) $[4,5]$, and the ribosomal synthesis of linear precursor peptides that are subjected to post-translational modifications and proteolytic processing [6, 7].

We have previously reported that SF214, a marine isolated strain of B. pumilus, produced two independent antimicrobials specifically active against Staphylococcus aureus or Listeria monocytogenes [8]. SF214 is known to produce a water soluble yellow-orange pigment, essential to protect the bacterium against oxidative stresses $[9,10]$. Synthesis of the still uncharacterized pigment of SF214 is a bistable process that occurs in alternative to spore formation [10]. Pigment synthesis, sporulation and matrix synthesis in SF214 are connected phenomena, controlled by the same master regulators [11]. The antimicrobial molecule active against $S$. aureus has been previously characterized as a pumilacidin, a nonribosomally synthesized cyclic lipopeptide of the surfactin class, composed of seven amino acid residues linked to fatty acids of variable length [8]. Here is reported that the antiListeria molecule produced by SF214 is a peptide with lytic and specific activity against growing cells of Listeria monocytogenes and that it is stable at conditions of low $\mathrm{pH}$ and high temperature.

\section{Results and Discussion \\ Exponentially growing cells of B. pumilus SF 214 produce a stable anti-Listeria molecule}

Bacillus pumilus SF214 produces during its exponential phase of growth an antimicrobial molecule apparently bigger than $10 \mathrm{kDa}$ active against the Listeria monocytogenes strain ATCC 7644 [8]. Production of antimicrobials during active growth is not common since most AMPs are secondary metabolites produced during the stationary phase of growth [3]. To confirm the previous observation and further characterize the synthesis of the anti-Listeria molecule, SF214 cells were grown in $\mathrm{S} 7$ medium at $25{ }^{\circ} \mathrm{C}$, and samples collected at various times. For each time point, the cell-free supernatant was size-fractionated and the $>10 \mathrm{kDa}$ fraction tested for the anti-Listeria activity, as previously reported [8]. The cell extracts of all time points were assayed for activities known to occur during the exponential or stationary phase of growth: the glucose-6-phosphate dehydrogenase $(\mathrm{G} 6 \mathrm{PDH})$ and the production of the orange pigment, respectively $[12,11]$. As reported in Fig. 1a, the anti-Listeria and G6PDH activities appeared during the active growth of SF214 cells (panel a) while the production of the pigment started later, at the entry into the stationary phase of growth (panel a). Results of Fig. 1a confirmed that actively growing cells of SF214 produce the antiListeria molecule but also indicated that the activity of such molecule appeared about one hour later than the G6PDH activity. This delay may be due to the secretion and eventual maturation/processing steps involved in the activation of some AMPs. An additional indication coming out of Fig. 1a is that the anti-Listeria activity persisted for several hours after its appearance.

This latter observation may be explained by a prolonged synthesis of the molecule, starting during the exponential growth and continuing during the stationary phase, or by the stability of the molecule that once produced remains active for a long time. To distinguish between these two possibilities, SF214 cells were grown as described above and the antibiotic chloramphenicol $(5 \mu \mathrm{g} / \mathrm{ml})$ added when cell reached $0.7 \mathrm{OD}_{600}$ (red arrow in Fig. 1b), immediately blocking growth. Cell-free supernatants, collected right before as well as 1 and $3 \mathrm{~h}$ after the antibiotic treatment, were size-fractionated and $>10 \mathrm{kDa}$ fractions tested for the anti-Listeria activity in plate assays. An identical antimicrobial activity ( $\mathrm{mm}$ of inhibition halo) was observed in the three samples, indicating that the inhibition of protein synthesis and growth did not reduce the antimicrobial activity and, therefore, suggesting that, once produced, the anti-Listeria 

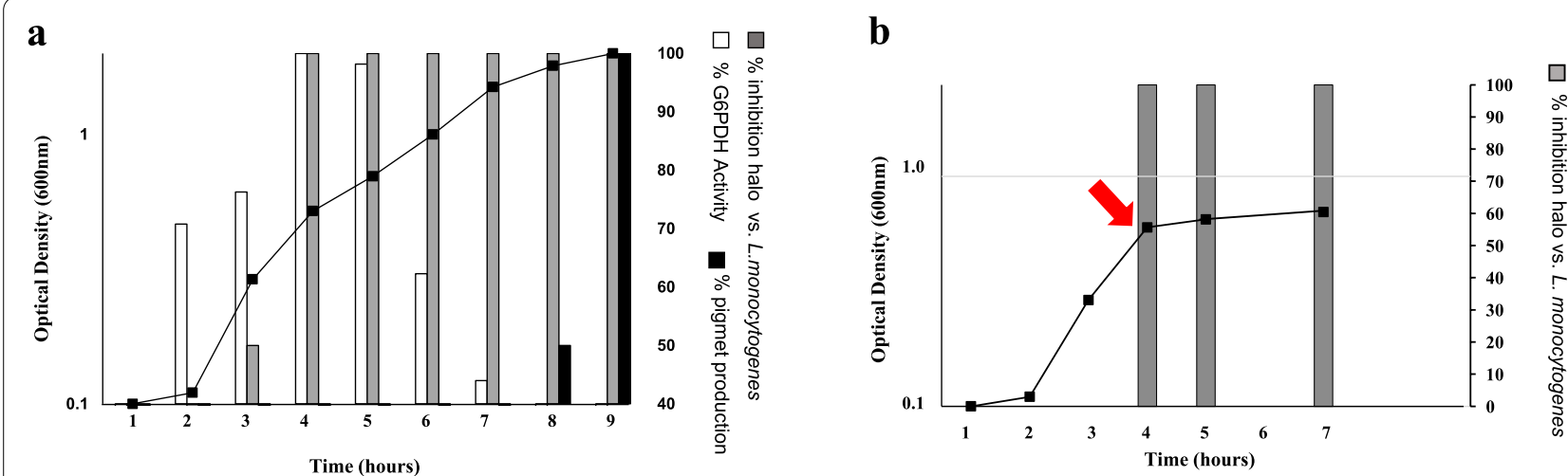

Fig. 1 Production of the antimicrobial during growth (a) and after a treatment with chloramphenicol (b). In (a), aliquots of the cell culture were collected at all-time points, the cell-free supernatant size-fractionated and the $>10 \mathrm{kDa}$ fraction tested against L. monocytogenes [8]. For all time points, cell extracts were analyzed for G6PD activity and pigment production as markers of of exponential and stationary phase of growth, respectively. The antimicrobial activities are reported as \% of growth inhibition ( $\mathrm{mm}$ of inhibition halo on plates) considering $100 \%$ the maximal activity observed. In (b) the red arrow indicates the time of chloramphenicol supplementation. Grey bars indicate the \% of antimicrobial activity (mm of inhibition halo on L. monocytogenes plates) considering 100\% the maximal activity observed before the antibiotic treatment

Table 1 Effect of $\mathrm{pH}$ on the anti-Listeria activity

\begin{tabular}{lll}
\hline $\mathbf{p H}$ & $\mathbf{1}$ hour $^{\mathbf{a}}$ & $\mathbf{5 \text { hours } ^ { \mathbf { a } }}$ \\
\hline 2 & 7.5 & 7.5 \\
4 & 7.5 & 7.5 \\
7 & 10 & 10 \\
10 & 10 & 10 \\
13 & 10 & 10 \\
\hline
\end{tabular}

a Diameter (mm) of the inhibition halo in plate assay

molecule remains stable for at least three hours in the cytoplasm of resting cells (Fig. 1b).

Stability of the anti-Listeria molecule was also tested over a wide range of $\mathrm{pH}$ and temperature conditions and after treatments with chemicals and enzymes. The antiListeria molecule was similarly active against its target cells after 1 or $5 \mathrm{~h}$ of incubation at $\mathrm{pH}$ values ranging from 7.0 to 13.0, was only slightly reduced at $\mathrm{pH} 2.0$ and 4.0 (Table 1). It was fully active after 15 min of incubation at 60 or $80^{\circ} \mathrm{C}$ (Table 2) and slightly reduced after $15 \mathrm{~min}$ at $100{ }^{\circ} \mathrm{C}$ (Table 2). None of the organic solvents tested showed any effect on the antimicrobial that was totally degraded by both a trypsin or a proteinase $\mathrm{K}$ treatment (Table 2). Altogether, results of Tables 1 and 2 indicate that the anti-Listeria molecule is highly stable and of proteinaceous nature.

\section{The anti-Listeria molecule of SF214 is specifically active against $L$. monocytogenes}

The anti-Listeria molecule of SF214 has been previously found inactive against all other the Gram positive (Streptococcus faecalis, Staphylococcus aureus, Bacillus
Table 2 Effect of enzymes, solvents and heat on the anti-Listeria activity

\begin{tabular}{lc}
\hline Treatment & $\begin{array}{l}\text { Activity on } \\
\text { plate assay }\end{array}$ \\
\hline None & 10 \\
Trypsin $^{b}$ & 0 \\
Proteinase $^{b}$ & 0 \\
DNase $^{b}$ & 10 \\
Ribonuclease A $^{b}$ & 10 \\
Acetone $^{c}$ & 10 \\
Ethyl alcohol $^{c}$ & 10 \\
Chloroform $^{c}$ & 10 \\
Toluene $^{c}$ & 10 \\
15 min $60^{\circ} \mathrm{C}$ & 10 \\
$15{\text { min } 80^{\circ} \mathrm{C}}^{15}$ min $100^{\circ} \mathrm{C}$ & 10 \\
\hline
\end{tabular}

a Diameter $(\mathrm{mm})$ of the inhibition halo in plate assay

${ }^{\mathrm{b}}$ Enzyme concentration was $100 \mu \mathrm{g} / \mathrm{ml}$

c A $10 \%(v / v)$ concentration was used

megaterium, Mycobacterium smegmatis, Enterococcus faecalis) or negative (Citrobacter freundii, Pseudomonas fluorescens, Shigella sonnei, Escherichia coli, Salmonella enterica) bacteria tested [8]. Here, the $>10 \mathrm{kDa}$ fraction of the SF214 cell-free supernatant was tested and found active against five other strains $L$. monocytogenes and but inactive against of Listeria innocua (Table 3). L. innocua is a non-pathogenic species of the Listeria genus, very similar to $L$. monocytogenes [14]. The two species have a genome of very similar size $(2.94$ and $3.01 \mathrm{Mb}$ for $L$. monocytogenes and $L$. innocua, respectively), 
Table 3 List of Listeria strains used for the antimicrobial activity

\begin{tabular}{ll}
\hline Species & Strain \\
\hline Listeria monocytogenes & ATCC 7644 \\
Listeria monocytogenes & ATCC 19,115 \\
Listeria monocytogenes & LM012018 $^{\mathrm{a}}$ \\
Listeria monocytogenes $_{\text {Listeria monocytogenes }}$ & LM001 $^{\mathrm{b}}$ \\
Listeria monocytogenes & ATCC 13,932 \\
Listeria innocua & ATCC 19,111 \\
Listeria innocua & ATCC 33,090 \\
Listeria innocua & BUG $499[13]^{\mathrm{C}}$ \\
\hline
\end{tabular}

Generous gifts from ${ }^{\mathrm{a}} \mathrm{M}$. Guida (Federico II University, Naples, Italy); ${ }^{\mathrm{b}} \mathrm{E}$. Ghelardi

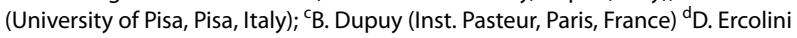
(Federico II University, Naples, Italy)

characterized by a high number of genes coding for surface and secreted proteins, transporters, and transcriptional regulators [15]. Although the human pathogen $L$. monocytogenes and the non-pathogenic $L$. innocua are strict relatives $[14,15]$, a comparative proteome analysis of the secreted and cell wall-associated proteins of the two bacteria revealed over $50 \mathrm{~L}$. monocytogenes-specific proteins [16]. In addition to known virulence factors, this subgroup of proteins includes proteins with a putative role in cell wall metabolism, transporters, penicillin binding proteins, cell division and motility proteins [15]. The anti-Listeria molecule of SF214 is, therefore, highly specific and for this reason peculiar with respect to other
AMPs that have a broad spectrum of action [1-3]. Examples are the recently discovered Amyloliquecidic GF610 of $B$. velenzensis [17] and a molecule produced by $B$. amyliquefaciens JFL21 [18], both active against Listeria but also against several Gram-positives and the latter also against some fungal pathogens. For its specificity and its proteinaceous nature the SF214 molecule will be therein indicate as specific anti-Listeriamonocytogenespeptide (SAMP) and all further analyses performed with $L$. monocytogenes ATCC 7644 as the target bacterium.

\section{SAMP has a lytic activity}

In order to characterize the antimicrobial activity of SAMP, $L$. monocytogenes cells were grown in LB medium at $37{ }^{\circ} \mathrm{C}$, up to $0.3 \mathrm{OD}_{600}$ (black arrow in Fig. $2 \mathrm{a}$ ), then supplemented with different amounts of the $>10 \mathrm{kDa}$ fraction of the cell-free supernatant of SF214 and growth monitored for several hours. While $5 \%$ and $10 \%$ (vol $/ \mathrm{vol})$ of supernatant showed respectively a slight reduction of growth and a bacteriostatic effect on L. monocytogenes, $20 \%$ of it rapidly killed all cells, suggesting for the antimicrobial a lytic activity (Fig. 2a). Stationary cells of $L$. monocytogenes not treated with the anti-microbial were collected at the time indicated by the red arrow in Fig. 2a, incubated with supernatant $20 \%$ (vol/vol) for 3 and $16 \mathrm{~h}$ and plated for CFU analysis. No CFU reduction was observed (not treated: $\mathrm{T}_{0}=1.10 \times 10^{9} ; \mathrm{T}_{3}=0.99 \times 10^{9}$; $\mathrm{T}_{16}=1.28 \times 10^{9} \quad$ CFUs; after supernatant treatment: $\mathrm{T}_{0}=1.10 \times 10^{9} ; \mathrm{T}_{3}=1.30 \times 10^{9} ; \mathrm{T}_{16}=1.29 \times 10^{9} \quad$ CFUs),

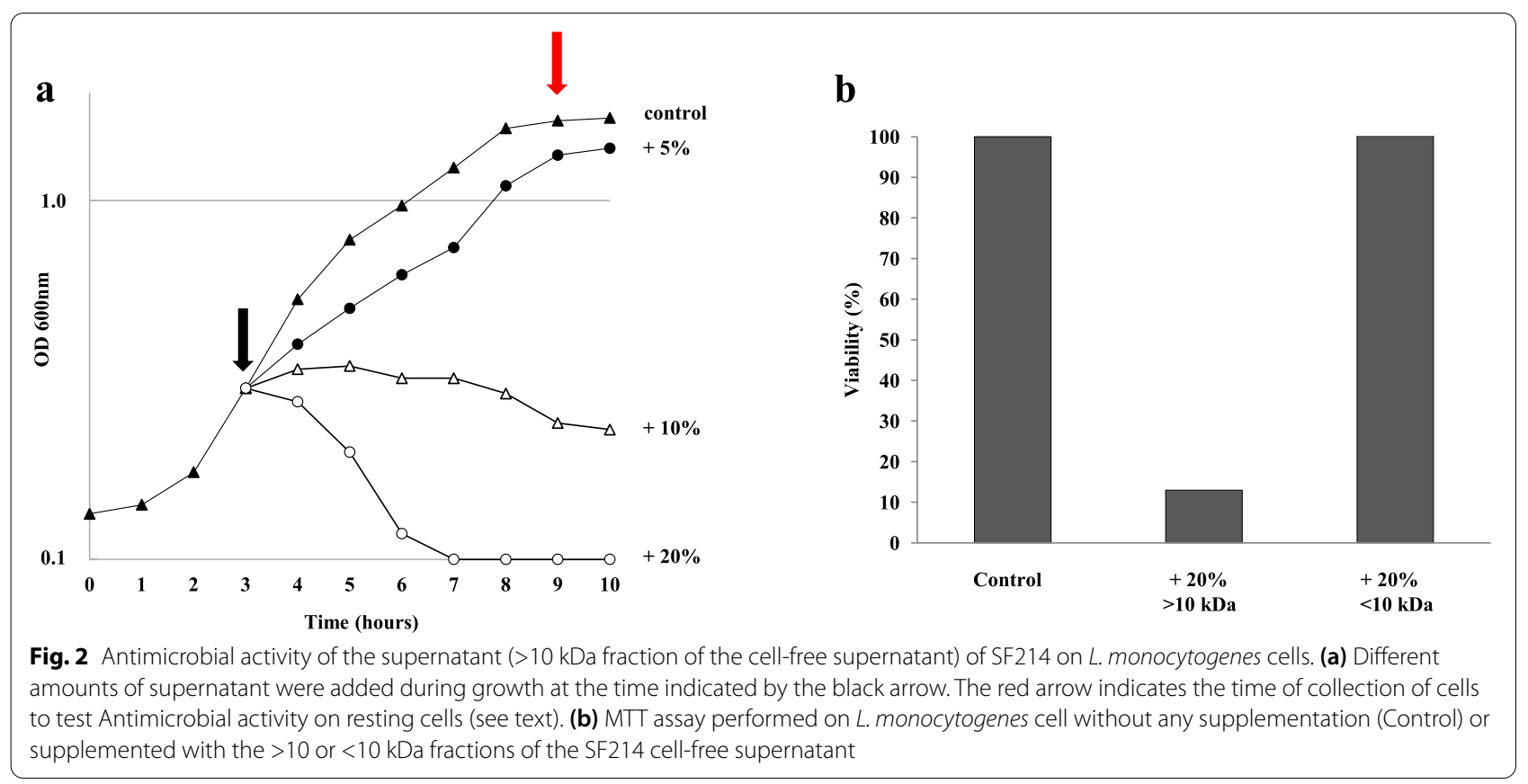


indicating that the antimicrobial was only active against growing cells of $L$. monocytogenes.

The lytic activity of SAMP was also confirmed by a colorimetric (MTT) assay that, by measuring the intracellular $\mathrm{NAD}(\mathrm{P}) \mathrm{H}$-dependent oxidoreductase activity, indicates the metabolic activity of cells. As shown in Fig. $2 \mathrm{~b}$, growing cell of $L$. monocytogenes $(\mathrm{OD} 600=0.6$ ) treated with $20 \%(\mathrm{vol} / \mathrm{vol})$ of the $>10 \mathrm{kDa}$ fraction of the SF214 cell-free supernatant, showed a strong reduction of the enzymatic activity and therefore of their viability with respect to the untreated cells and to cells treated with the same amount of the $<10 \mathrm{kDa}$ fraction of the SF214 cellfree supernatant, inactive against $L$. monocytogenes.

The effects of SAMP on L. monocytogenes cells were visualized by fluorescence microscopy after co-staining of the cells with 4,6-diamidino-2-phenylindole (DAPI) and propidium iodide (PI). The membrane-permeable DAPI stains all cells that appear blue while PI enters only damaged/death cells that appear red [19, 20]. As reported in Fig. 3, only blue cells were observed when the supernatant was not used while death (red) cells appeared after the antimicrobial treatment. Incubation for $4 \mathrm{~h}$ with increasing concentrations of the antimicrobial produced an increasing number of damaged/death (red) cells and only red cells were found at the highest concentration of antimicrobial used in the experiment (20\%) (Fig. 3). This assay clearly shows an increased permeability of the $L$. monocytogenes cells in response to the treatment, indicating that the bactericidal effect occurs through membrane permeabilization and surface damages.
The morphological defects due to the supernatant were visualized by a Scanning Electron Microscopy (SEM) analysis. L. monocytogenes cells treated for $4 \mathrm{~h}$ with $20 \%$ (vol/vol) supernatant showed distinct morphological changes (Fig. 4). Untreated cells appeared intact (Fig. 4a) while supernatant-treated cells showed on their surface cell debris (white arrows in Fig. 4b, c, d), an indication of the loss of cell integrity, similar to what detected with other antimicrobials affecting the membrane integrity $[20,21]$. Interestingly, the defects observed after treatment with SAMP appeared different from those caused by another anti-Listeria compound. After a treatment with the commercially available Linalool the Listeria cell surface appeared by SEM analysis as a wrinkled [22] and did not show the cell debris observed in Fig. 4, suggesting a different mechanism of action for Linalool and SAMP.

To evaluate the toxicity of SAMP against eukaryotic cells, an MTT assay with human epithelial (Caco-2) cells was performed. SF214 supernatant $\mathrm{w}(20 \% \mathrm{vol} / \mathrm{vol})$ was added to the growth medium of the Caco- 2 cells. No effects on cell viability were observed after $24 \mathrm{~h}$ of incubation suggesting that SAMP is not toxic for human cells (not shown).

\section{Characterization of SAMP}

To expand the preliminary observation that SAMP has a proteinaceous nature (Tables 1 and 2 ), the $>10$ Da fraction of the SF214 supernatant was analyzed on a $18 \%$ SDS-PAGE. As shown in Fig. 5a, about a dozen proteins ranging from slightly less than 10 to over $50 \mathrm{kDa}$ was

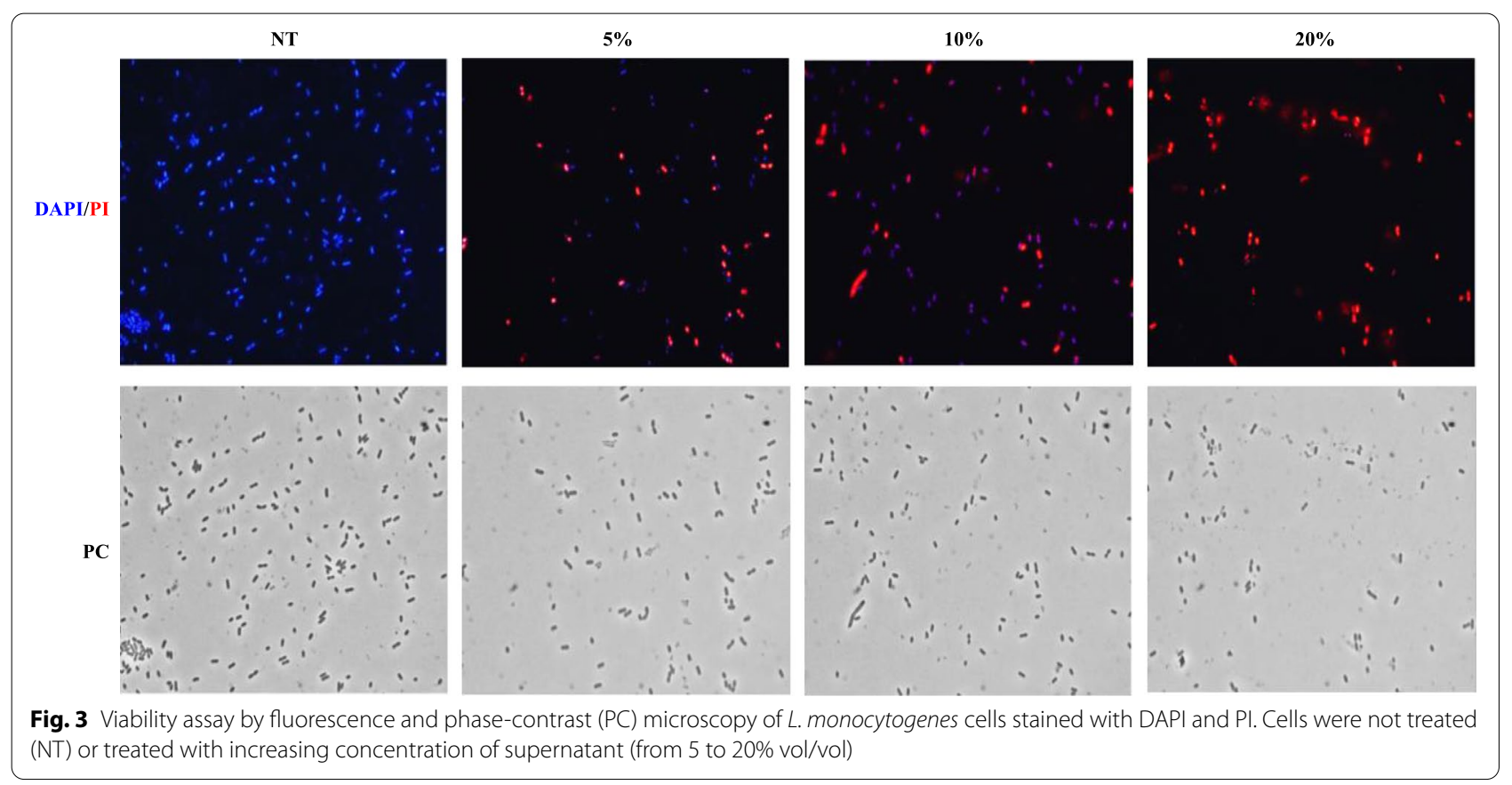



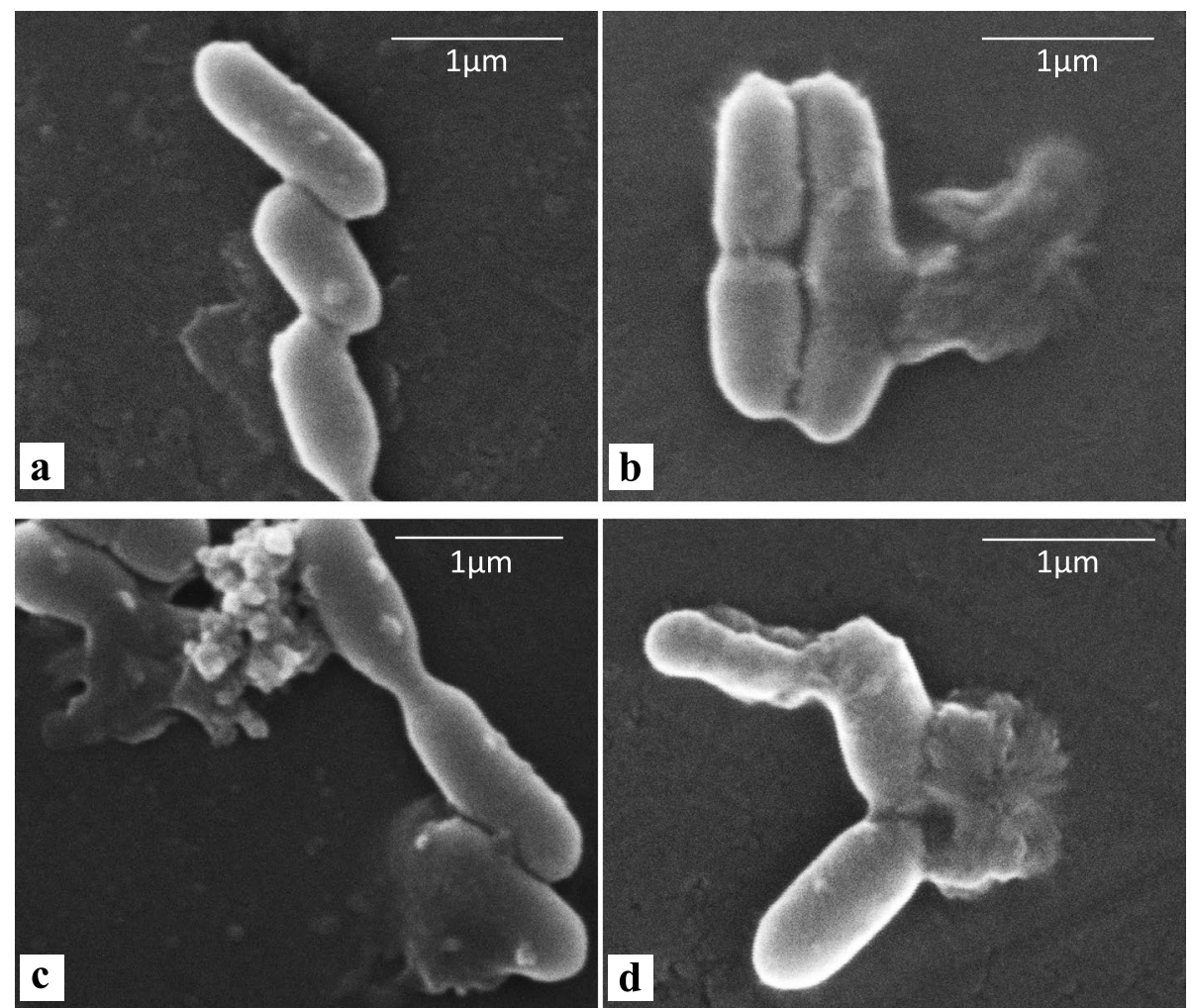

Fig. 4 Scanning Electron Microscopy (SEM) analysis of L. monocytogenes cells not treated (a) or treated for $4 \mathrm{~h}$ with 20\% (vol/vol) of supernatant $(\mathbf{b}, \mathbf{c}, \mathbf{d})$. White arrows indicate points of cell rupture

observed. A second gel was run in parallel, not stained with Coomassie-Blue but fixed and overlaid with softagar containing L. monocytogenes cells for direct detection of antimicrobial activity as previously described [23]. As shown in Fig. 5b, the anti-Listeria activity was associated with a band of apparent molecular mass slightly smaller than $10 \mathrm{kDa}$.

Although smaller than $10 \mathrm{kDa}$ (Fig. 5b), SAMP did not pass through filters with a $10 \mathrm{kDa}$ cut-off, suggesting the formation of aggregates dissolved during the SDS PAGE. To evaluate whether such potential high molecular weight aggregates were due to hydrophobic interactions, different amounts of methanol were added to the cellfree supernatant of SF214 to obtain final methanol concentrations of 20,50 or $75 \%$. Methanol was selected as solvent because it is known to weaken the hydrophobic interactions between proteins or between amino acids of the same protein [24] and because it did not have any inhibitory activity on L. monocytogenes at the used concentrations (not shown). After size-fractionation the $<10$ and $>10 \mathrm{kDa}$ fractions of the supernatant were diluted to the same final volume $(10 \mathrm{ml})$ and aliquots tested for anti-Listeria activity. While $20 \%$ methanol did not have effects on SAMP and the anti-Listeria activity was found only in the $>10 \mathrm{kDa}$ fraction, in the presence of 50 and $75 \%$ methanol the activity was found only in the $<10 \mathrm{kDa}$ fraction (Table 4), suggesting that in 50 and $75 \%$ methanol SAMP did not form aggregates as in water or $20 \%$ methanol. Formation of high molecular weight aggregates and micelles by antimicrobials produced by Bacillus has been recently reported [25], supporting the conclusion based on data of Fig. 5; Table 4.

\section{Genome analysis}

The genome sequence of SF214 [11] was analysed to search for homologs of genes coding for potential antimicrobial peptides and for NRPS/PKS, responsible for the non-ribosomal synthesis of peptides and polyketides. The coding gene of most ribosomally-synthesized antimicrobials produced by members of the Bacillus genus has not been identified, therefore the search for homologs was limited to some of the AMPs whose coding gene is known. As reported in Table 5, the SF214 genome encodes proteins with only a limited identity with known antimicrobials produced by Bacilli. The highest identity observed was 53\% found between WP_060596419.1 of SF214 and Subtilosin A of B. subtilis (Table 5). However, Subtilosin A unlikely corresponds to SAMP since 
$\mathbf{a}$

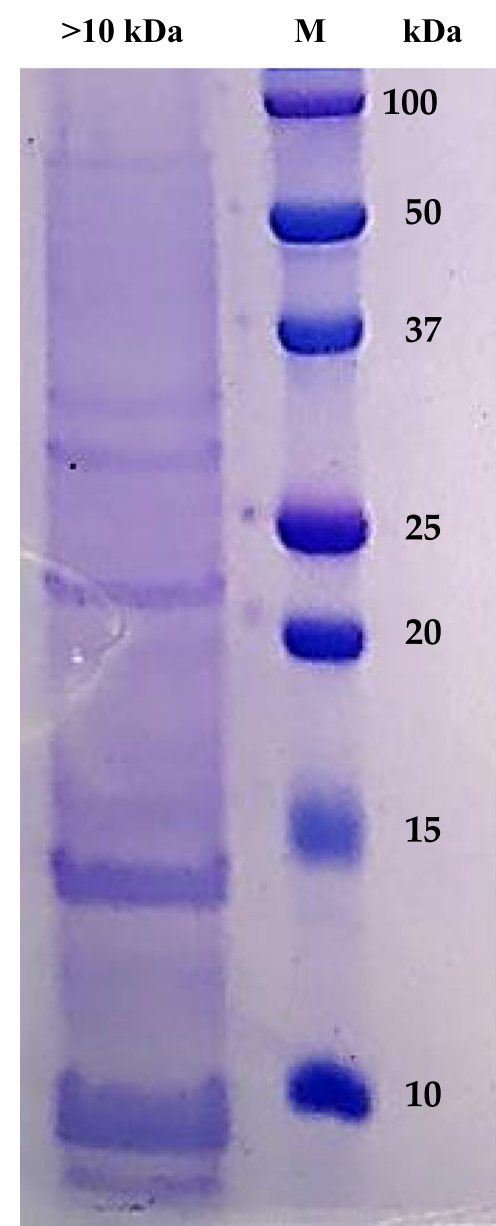

b

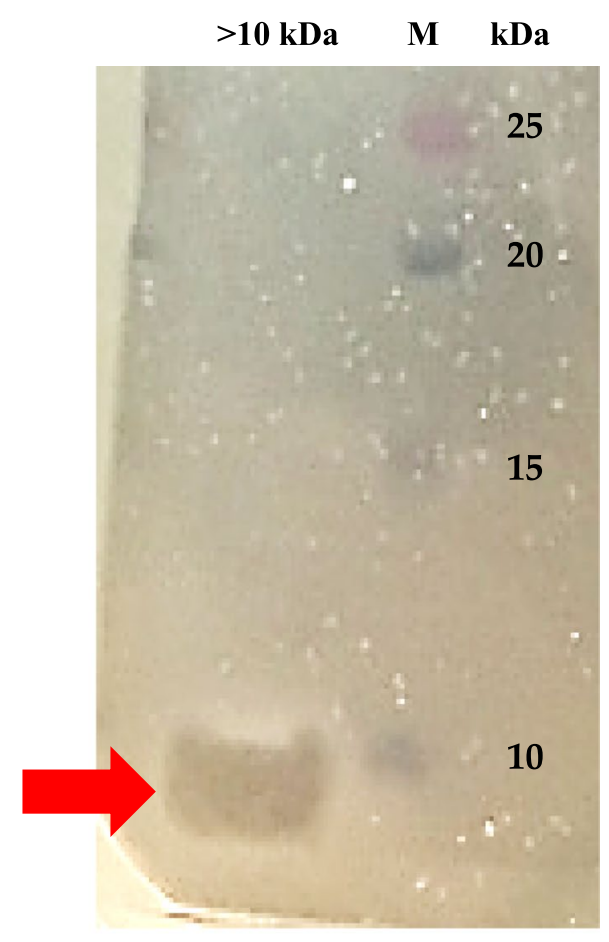

Fig. 5 SDS-PAGE analysis of the $>10 \mathrm{kDa}$ fraction of the cell-free supernatant of SF214. (a) Coomassie-Blue stained 18\% polyacrylamide gel. (b) 18\% polyacrylamide gel not stained but fixed and overlaid with L. monocytogenes cells. The red arrow points to the inhibition halo observed after $18 \mathrm{~h}$ of incubation at $37^{\circ} \mathrm{C}$. M: molecular marker

Table 4 Effect of methanol on antimicrobial activity

\begin{tabular}{lll}
\hline $\begin{array}{l}\text { Methanol } \\
(\%)\end{array}$ & $>10 \mathrm{kDa}^{\mathrm{a}}$ & $<10 \mathrm{kDa}^{\mathrm{a}}$ \\
\hline 0 & + & - \\
20 & + & - \\
50 & - & + \\
75 & - & + \\
\hline
\end{tabular}

${ }^{a}$ Inhibition halo in plate assay: $-=$ no halo; $+=$ presence of halo

it is active against members of the Bacillus and Enterococcus genus [26] that are not affected by SAMP [8]. A bioinformatic analysis, performed by using the AntiSmash (https://antismash.secondarymetabolites.org) and tools available on the PKS/NRPS Analysis Website (http://nrps.igs.umaryland.edu/), identified four clusters potentially coding for NRPS/PKS. These four clusters were further analysed by the HMMER tool (https://www. ebi.ac.uk/Tools/hmmer/) [27] to predict their potential products (Table 5). Cluster SF214_0323-SF214_0328 corresponds to the $s r f A-s f p$ locus, responsible of the synthesis of the Pumilacidin active against $S$. aureus and previously characteried [8], while the other three clusters were predicted to encode products formed by one (SF214_0601), two (SF214_3715-SF214_3717) or six (SF214_0611-SF21_0615) amino acids (Table 6), all too small for the predicted size of SAMP. Therefore, we conclude that none of the clusters identified by our in silico analysis is likely to encode for the amino acids forming SAMP. Based on the results of Tables 5 and 6, we hypothesize that SAMP is produced by transcription and translation of a structural gene and that is not a previously characterized molecule. Confirming such hypothesis will 
Table 5 Percentage of identity of known ribosomallysynthesized antimicrobials of Bacilli with proteins encoded by the SF214 genome

\begin{tabular}{ll}
\hline Antimicrobials & $\begin{array}{l}\text { Highest Identity } \\
\text { (\%) hit } \\
\text { on the SF214 } \\
\text { translated genome }\end{array}$ \\
\hline Subtilin [27] & WP_060597202.1 (37) \\
Bacthuricin F4 [28] & WP_060595519.1 (31) \\
Subtilin JS-4 [29] & WP_060597425.1 (34) \\
Cerecin [28] & WP_060597533.1 (39) \\
Antimicrobial peptide LCl [30] & WP_060596412.1 (47) \\
EricinA [27] & WP_060597202.1 (36) \\
Mersacidin [27] & WP_060596204.1 (34) \\
EricinS [27] & WP_012010311.1 (45) \\
Sublancin 168 [27] & WP_050944681.1 (42) \\
Subtilosin A [27] & WP_060596419.1 (53) \\
Clausin [30] & WP_060595627.1 (42) \\
Lichenicidin [30] & WP_003217179.1 (43) \\
Plantazolicin [30] & WP_060596638.1 (38) \\
Haloduracin [31] & WP_060595537.1 (25) \\
Amyloliquecidin GF610 [17] & WP_034659961.1 (43) \\
Coagulin A [28] & WP_060596970.1 (31) \\
\hline
\end{tabular}

Table 6 Genes potentially coding for NRPS/PKS ${ }^{a}$ in the SF214 genome

\begin{tabular}{ll}
\hline Cluster & Predicted product \\
\hline SF214_0323-SF214_0328 & glu-leu-leu-X-asp-leu-ile-val \\
SF21_0601 & asn \\
SF214_0611-SF214_0615 & asn-ohmal-glu-ohmal-ohmal-ohmal \\
SF214_3715-SF214_3717 & gly-tyr \\
\hline
\end{tabular}

${ }^{a}$ NRPS: non-ribosomal peptide synthase, PKS: polyketide synthase;

b ohmal: hydroxymalonil

be a future challenge that will need to be based on the chemical characterization of the antimicrobial, a step so far impaired by the small amount of SAMP produced by SF214.

\section{Conclusions}

The main conclusion of this report is that B. pumilus SF214 during its exponential phase of growth produces an antimicrobial with a lytic activity specifically against growing cells of L. monocytogenes. Production of an antimicrobial by a Bacillus strain is clearly not a new observation since hundreds of them have been previously described. However, SAMP has unravelled some peculiar properties that make this molecule unusual and worth studying:
- - SAMP is not a typical secondary metabolite, as most AMPs [2, 3, 6, 7]. It is produced at the mid exponential phase of growth of B. pumilus SF214 but about one hour later than G6PDH. Such delay could be due to the need of post-synthesis maturation events (for example, processing of a secretion signal), inducing the hypothesis that it is a ribosomally synthesized peptide. This hypothesis is also supported by the in-silico analysis of the SF214 genome, that did not show the presence of homologs of already known AMPs or of genes coding for NRPs suited to synthesize the anti-L. monocytogenes molecule.

- - SAMP affects cell wall integrity of growing but not resting cells of L. monocytogenes, suggesting the cell wall synthesis machinery rather than structural components of the cell membrane as the target of action.

- - SAMP is specifically active against L. monocytogenes and is not active even against strains of the close relative species L. innocua.

- - SAMP is not toxic for human cells.

\section{Methods}

\section{Bacterial strains, growth conditions and preparation of cell-free fractions}

Bacillus pumilus SF214, Listeria monocytogens and L. innucua strains reported in Table 3 were grown either in $\mathrm{LB}$ broth $(8 \mathrm{~g} / \mathrm{L} \mathrm{NaCl}, 10 \mathrm{~g} / \mathrm{L}$ tryptone, $5 \mathrm{~g} / \mathrm{L}$ yeast extract), BHI (Brain Heart Infusion) or (only B. pumilus) in $\mathrm{S} 7$ minimal medium (50 $\mathrm{mM}$ morpholine-propanesulfonic acid (MOPS) (adjusted to $\mathrm{pH} 7.0$ with $\mathrm{KOH}$ ), 10 $\mathrm{mM}\left(\mathrm{NH}_{4}\right)_{2} \mathrm{SO}_{4}, 5 \mathrm{mM}$ potassium phosphate (pH 7.0), 2 $\mathrm{mM} \mathrm{MgCl} 2,0.9 \mathrm{mM} \mathrm{CaCl}_{2}, 50 \mu \mathrm{M} \mathrm{MnCl}_{2}, 5 \mu \mathrm{M} \mathrm{FeCl}_{3}, 10$ $\mu \mathrm{M} \mathrm{ZnCl}_{2}, 2 \mu \mathrm{M}$ thiamine hydrochloride, $20 \mathrm{mM}$ sodium glutamate, $1 \%$ glucose, $0.1 \mathrm{mg} / \mathrm{mL}$ phenylalanine, and $0.1 \mathrm{mg} / \mathrm{mL}$ tryptophan) and cells grown in aerobic conditions at $25{ }^{\circ} \mathrm{C}$. SF214 cultures were centrifuged (1000x $\mathrm{g}$ for $10 \mathrm{~min}$ at Room Temperature) and the supernatant filter-sterilized with a $0.22-\mu \mathrm{m}$ filter (Millipore, Bedford, MA, USA). The supernatants were size-fractionated (10kDa cutoff spin column; Centricon, Millipore) by centrifuging $11,000 \mathrm{~g}$ for $10 \mathrm{~min}$ at $4{ }^{\circ} \mathrm{C}$. The fraction $<10 \mathrm{kDa}$ was concentrated 5 folds by a vacuum speed concentrator (Eppendorf).

\section{Antimicrobial activity on Plate Assay and on gel}

Antimicrobial activity was determined as previously described [23] with the following modifications: $10 \mu \mathrm{L}$ of concentrated (see above) $<10$ or $>10 \mathrm{kDa}$ fractions of the cell-free supernatant were spotted on the surface of a sterile LB agar plate and the spots air-dried. $100 \mu \mathrm{L}$ of $L$. monocytogenes or L. innocua culture was mixed with 10 $\mathrm{mL}$ of soft agar $(0.7 \%)$ and poured over the plate. Fresh 
media and ampicillin $(1 \mu \mathrm{g} / \mathrm{mL})$ were used as negative and positive controls, respectively. The plates were incubated aerobically overnight at $37^{\circ} \mathrm{C}$ and the inhibition halos were measured and reported in $\mathrm{mm}$.

For the direct detection of the antibacterial activity on gel, 50 ug of total proteins of the $>10 \mathrm{Da}$ fraction of SF214 cell-free supernatant were split in two identical samples and loaded in two independent lanes of a sodium dodecyl sulfate-polyacrylamide gel electrophoresis (SDS PAGE, 18\%). After about $1.5 \mathrm{~h}$, the gel was removed and cut into two vertical parts. One part of the gel, containing one sample and the molecular weight standards, was stained with Coomassie brilliant blue R250 (Sigma). The other part of the gel was tested for antimicrobial activity as previously described [23] with the following modifications: the gel was fixed immediately by a 2 -h treatment in $20 \%$ isopropanol-10 mM Tris- $\mathrm{HCl}$ (pH 7.5) and 1-hour treatment in $20 \%$ isopropanol $(\mathrm{pH} 7.5)$ and $10 \%$ acetic acid, and at the end washed for $3 \mathrm{~h}$ in $10 \mathrm{mM}$ Tris- $\mathrm{HCl}$ $(\mathrm{pH}$ 7.5). The gel was then placed into a petri dish, airdried for $10 \mathrm{~min}$ and overlaid with $15 \mathrm{ml}$ of $0.7 \%$ agar containing $10^{6}$ cells of the indicator strain. The dish was then incubated at $30{ }^{\circ} \mathrm{C}$ for about $16 \mathrm{~h}$ and analyzed for an inhibition halo.

\section{Detection of pigment production and of G6PDH activity}

To evaluate pigment production, SF214 growth cultures were centrifugated at $7000 \mathrm{rpm}$ for $10 \mathrm{~min}$, the pellet was washed two times with lysis buffer $(50 \mathrm{mM}$ Tris- $\mathrm{HCl} \mathrm{pH}$ 7.5, $1 \mathrm{mM}$ DTT, $0.1 \mathrm{mM}$ PMSF,10\% glycerol), suspended in the same buffer and sonicated at $4{ }^{\circ} \mathrm{C}$ for $10 \mathrm{~min}(30 \mathrm{~s}$. $\mathrm{ON}$ and $30 \mathrm{~s}$. OFF). After centrifugation at 13,000 rpm for $15 \mathrm{~min}$, supernatants were used to quantify the total protein concentration by the Bradford assay using bovine serum albumin (BSA) as standard protein. Samples of identical protein concentration were then used to determine the pigment content by following the adsorbance spectrum between 300 and $550 \mathrm{~nm}$, as previously reported [10].

G6PDH activity was analyzed at $25{ }^{\circ} \mathrm{C}$ by measuring the reduction of NADP+ to NADPH at $340 \mathrm{~nm}$ by G6PDH in the presence of glucose-6-phosphate (G6P) in a $1 \mathrm{~cm}$ cuvette in a spectrophotometer Cary 60 (Agilent Technologies) as previously reported [12]. Assays were always carried out in duplicates. The reaction mixture (final volume $1 \mathrm{ml}$ ) contained $5 \mathrm{mM} \mathrm{MgCl}, 150 \mu \mathrm{M}$ NADP+, and $3 \mathrm{mM}$ G6P in $30 \mathrm{mM}$ Tris- $\mathrm{HCl}$ buffer, $\mathrm{pH}$ 7.5. $50 / 100 \mu \mathrm{l}$ of supernatant were utilized; blank without G6P. One unit of enzyme (U) activity defined as the amount of enzyme that reduced $1 \mu \mathrm{mol}$ NADP+ per minute, the total activity was expressed as units per $\mathrm{mg}$ of protein. The determination of total protein concentrations was performed as described above.

\section{Stability of Antimicrobial at Different pH, Temperature, Chemical, and Enzyme Conditions}

The effects of $\mathrm{pH}$ and heat on supernatants were analyzed by assaying the antimicrobial activity after 1 or $5 \mathrm{~h}$ of incubations at $30^{\circ} \mathrm{C}$ in $50 \mathrm{mM}$ phosphate buffer (pH 6.0), adjusted to the various $\mathrm{pH}$ with $\mathrm{HCl}$ and $\mathrm{NaOH}$ and after 15 min of incubation at 60,80 , and $100{ }^{\circ} \mathrm{C}$ (Tables 1 and 2). Enzymes $(100 \mu \mathrm{g} / \mathrm{mL})$ and $10 \%$ organic solvents were added to $100 \mu \mathrm{L}$ of culture supernatant. Enzyme-treated samples were incubated $1 \mathrm{~h}$ at $37{ }^{\circ} \mathrm{C}\left(42{ }^{\circ} \mathrm{C}\right.$ in the case of proteinase $\mathrm{K}$ ) and solvent-treated samples were incubated for 1 or $5 \mathrm{~h}$ at $25{ }^{\circ} \mathrm{C}$, and subsequently, $10 \mu \mathrm{L}$ aliquots were tested for antimicrobial activity as described above (Table 2).

\section{MTT assays}

Cytotoxicity on L. monocytogenes cells was assessed by performing the (3-(4,5-dimethylthiazol-2-yl)-2,5 diphenyltetrazolium bromide) (MTT) reduction inhibition assay. Cells were grown in LB medium at $37{ }^{\circ} \mathrm{C}$, thoroughly washed and resuspended in $\mathrm{PBS}+0.2 \%$ glucose reaching a final $\mathrm{OD}_{600}$ of 0.6. 100ul of cells were incubated at $37^{\circ} \mathrm{C}$ with SF214 cell-free supernatant $>10 \mathrm{kDa}$ $20 \%(\mathrm{v} / \mathrm{v})$, SF214 cell-free supernatant $<10 \mathrm{kDa} 20 \%(\mathrm{v} / \mathrm{v})$ and PBS $0.2 \%$ glucose (control) respectively. After $3 \mathrm{~h}$ of incubation cells were gently centrifuged to remove the supernatant, resuspended in 90ul of PBS $+0.2 \%$ glucose, moved into 96-well plate and $10 \mu \mathrm{l}$ of a stock MTT reagent was added into each well. The samples were incubated on a thermostatic shaker at $37{ }^{\circ} \mathrm{C}$ and $200 \mathrm{rpm}$ in the dark. After $30 \mathrm{~min}, 100 \mu \mathrm{l}$ of DMSO per well was added and plates were incubated for $15 \mathrm{~min}$ at room temperature in the dark (complete formazan dissolution was detected). The absorbance of each well at $560 \mathrm{~nm}$ was measured using a microplate reader (Thermo, Multiskan Spectrum) [32]. The MTT reagent was prepared by dissolving $5 \mathrm{mg}$ of 3-(4,5-dimethylthiazol-2-yl)-2,5-diphenyl-tetrazolium bromide (MTT) (Sigma-Aldrich) in $1 \mathrm{ml}$ PBS. DMSO was used for solubilization of the formazan crystals.

Cytotoxicity on human cells was performed by using epithelial (Caco2) cells that were cultured in Dulbecco's modified Eagle's medium (Sigma Aldrich, Milan, Italy) supplemented with $10 \%$ fetal bovine serum (HyClone, GE Healthcare Lifescience, Chicago, IL) and $1 \%$ penicillinstreptomycin, at $37{ }^{\circ} \mathrm{C}$ in humidified atmosphere of $5 \%$ $\mathrm{CO} 2$.

Cytotoxicity on $\mathrm{CaCo}-2$ cells was assessed by performing the MTT reduction inhibition assay. Cells were grown as described and plated on 96 well plates at a density of $5 \times 10^{3}$ cells per well, in $200 \mu \mathrm{l}$ of medium containing the $>10 \mathrm{kDa}$ fraction of the SF214 cell-free supernatant $(20 \% \mathrm{v} / \mathrm{v})$ for $24 \mathrm{~h}$. After treatment, the medium was 
eliminated and $10 \mu \mathrm{l}$ of a MTT solution $(5 \mathrm{mg} / \mathrm{ml})$ was added to the cells to a final concentration of $0.5 \mathrm{mg} / \mathrm{ml}$. After $4 \mathrm{~h}$ incubation, the MTT solution was removed and the MTT formazan salts were dissolved in $100 \mu \mathrm{l}$ of DMSO. Cell survival was expressed as the absorbance of blue formazan measured at $570 \mathrm{~nm}$ with an automatic plate reader (Multi scan spectrum; Thermo-Fisher Scientific, Waltham, MA, USA). Cytotoxicity tests were performed at least 3 times and cell survival values expressed as percentage of viable cells with respect to control untreated sample.

\section{DAPI/IP dual staining, fluorescence and SEM microscopy}

For dual staining, $200 \mu \mathrm{l}$ of bacterial culture (grown to mid-logarithmic phase) were incubated in the dark for 4 hours at $37^{\circ} \mathrm{C}$ in agitation without or with increasing concentration ( 5 to $20 \% \mathrm{vol} / \mathrm{vol}$ ) of the $>10 \mathrm{kDa}$ fraction of the SF214 cell-free supernatant. After the incubation $10 \mu \mathrm{l}$ of bacterial culture were mixed with $1.5 \mu \mathrm{l}$ DAPI solution (4,6-diamidino-2-phenylindole dihydrochloride; Sigma Aldrich) $(1 \mu \mathrm{g} / \mathrm{ml}$ DAPI final concentration) and $1.5 \mu \mathrm{l}$ of PI (propidium iodide $20 \mu \mathrm{g} / \mathrm{ml}$ final concentration; Sigma Aldrich) and incubated in the dark for $30 \mathrm{~min}$ at room temperature [19]. Samples were observed with an Olympus BX51 fluorescence microscope (Olympus, Tokyo, Japan) using a DAPI/TRITC filters (standard acquisition times were $200 \mathrm{~ms}$ ). Images were captured using an Olympus DP70 digital camera.

For SEM analysis, $L$. monocytogenes cells were grown in LB to an exponential phase, harvested by centrifugation at $11,000 \mathrm{~g}$ for $10 \mathrm{~min}$ and the pellet resuspended in $10 \mathrm{ml}$ of phosphate buffer (pH 7.0). An aliquot of $5 \mathrm{ml}$ containing $1 \times 10^{8}$ cells $/ \mathrm{ml}$ was incubated at $37^{\circ} \mathrm{C}$ for $4 \mathrm{~h}$ with $20 \%$ SF214-CFS (v/v) while the control (untreated) sample was incubated with phosphate buffer at the identical conditions. Then the samples were cut from subapical parts using a sharp razor blade, fixed with $3 \%$ glutaraldehyde in phosphate buffer (65 mM, pH 7.2-7.4) for $2 \mathrm{~h}$ at room temperature, post-fixed with $1 \%$ osmium tetroxide in the same phosphate buffer for $1.5 \mathrm{~h}$ at room temperature, and completely dehydrated with ethanol and critical point drying. Both samples were then mounted on aluminum stubs, coated with a thin gold film using an EdwardE306 Evaporator, and observed with a FEI (Hillsboro, OR, USA) Quanta 200 ESEM in high vacuum mode (P $70 \mathrm{~Pa}, \mathrm{HV} 30 \mathrm{kV}$, WD10 mm, spot 3.0).

\footnotetext{
Abbreviations

AMP: Anti-Microbial Peptide; FA: Fatty acid; NRPS: Non-Ribosomal Peptide Synthase; G6PDH: Glucose-6-Phosphate DeHydrogenase; SAMP: Specific Anti-Listeria Monocytogenes Peptide; CFU: Colony Forming Units.; MTT: 3-(4,5-dimethylthiazol-2-yl)-2,5 diphenyltetrazolium bromide; IP: propidium iodide.; DAPI: 4,6-diamidino-2-phenylindole dihydrochloride.; SEM: Scanning Electron Microscopy.
}

\section{Acknowledgements Not applicable.}

\section{Authors' contributions}

AS performed most experiments; YDL contributed to some of the experiments; $L B$ supervised the experimental work and contributed in writing the manuscript; ER supervised the work, was a major contributor in writing the manuscript and in fund rising. All authors have read and agreed to the published version of the manuscript.

\section{Funding}

This research was partially supported by Synergia Life Sciences (India). The funding body had no role in the design of the study, in the collection, analyses, or interpretation of data or in the writing of the manuscript.

\section{Availability of data and materials}

All data generated or analyzed during this study are included in this published article. Raw data are available on request by contacting the corresponding author by email (ericca@unina.it).

\section{Declarations}

Ethics approval and consent to participate Not applicable.

\section{Consent for publication}

Not applicable.

\section{Compiting intersts}

The authors declare the following financial interests/personal relationships which may be considered as potential competing interests.

- one of the authors (E. Ricca) acts as a consultant for Synergia Life Sciences (India) on the commercialization of probiotic strains.

- Synergia Life Sciences (India) has acquired commercial rights on the strain used in this study (Bacillus pumilus SF214) but had no role in the design of the study, in the collection, analyses, or interpretation of data or in the writing of the manuscript.

\section{Author details}

'Department of Biology, Federico II University, via Cinthia, Complesso Universitario di Monte Sant'Angelo, 80126 Naples, Italy. ${ }^{2}$ Department of Molecular Medicine and Medical Biotechnology, Federico II University, Naples, Italy.

Received: 7 September 2021 Accepted: 10 December 2021

Published online: 03 January 2022

\section{References}

1. Browne K, Chakraborty S, Chen R, Willcox MDP, StClair Black D, Walsh WR, Kumar N (2020) A New Era of Antibiotics: The Clinical Potential of Antimicrobial Peptides. Int J Mol Sci 21, 7047. https://doi.org/10.3390/ ijms21197047

2. Zhao P, Xue Y, Gao W, Li J, Zu X, Fu D, Bai X, Zuo Y, Hu Z, Zhang F. Bacillaceae-derived peptide antibiotics since 2000. Peptides. 2018;101:10-6. https://doi.org/10.1016/j.peptides.2017.12.018.

3. Cauller S, Nannan C, Gillis A, Licciardi F, Bragard C, Mahillon J. Overview of the antimicrobial compounds produced by members of the Bacillus subtilis group. Front Microbiol. 2019;10:302. https://doi.org/10.3389/ fmicb.2019.00302.

4. Silva Stenico ME, Souza C, Sturion A, Keiko T, Etchegaray A, Possedente S, Beraldo LA, Fatima M. Non-ribosomal peptides produced by Brazilian cyanobacterial isolates with antimicrobial activity. Microbiol Res. 2011;166:161-75. https://doi.org/10.1016/j.micres.2010.04.002.

5. Bruner SD, Weber T, Kohli RM, Schwarzer D, Marahiel MA, Walsh CT, Stubbs MT. Structural basis for the cyclization of the lipopeptide antibiotic surfactin by the thioesterase domain SrfTE. Structure. 2002;10:30110. https://doi.org/10.1016/S0969-2126(02)00716-5. 
6. Stein T. Bacillus subtilis antibiotics: structures, synthesis and specific functions. Mol Microbiol. 2005;56:845-57. https://doi.org/10.1111/j.1365-2958. 2005.04587.x

7. Harwood CR, Mouillon JM, Pohl S, Arnau J. Secondary metabolite production and the safety of industrially important members of the Bacillus subtilis group. FEMS Microbiol Rev. 2018;42:721-38. https://doi.org/10. 1093/femsre/fuy028.

8. Saggese A, Culurciello R, Casillo A, Corsaro MM, Ricca E, Baccigalupi L. A marine isolate of Bacillus pumilus secretes a pumilacidin active against Stephylococcus aureus. Mar Drugs. 2018;16:180. https://doi.org/10.3390/ md16060180.

9. Khaneja R, Perez-Fons L, Fakhry S, Baccigalupi L, Steiger S, To E, Sandmann G, Dong TC, Ricca E, Fraser PD, Cutting SM. Carotenoids Found in Bacillus. J Appl Microbiol. 2010;108:1889-902. https://doi.org/10.1111/j.13652672.2009.04590.x.

10. Manzo N, Di Luccia B, Isticato R, D'Apuzzo E, De Felice M, Ricca E. Pigmentation and sporulation are alternative cell fates in Bacillus pumilus SF214. PLoS ONE. 2013;8(4):e62093. https://doi.org/10.1371/journal.pone.00620 93.

11. Di Luccia B, Riccio A, Vanacore A, Baccigalupi L, Molinaro A, Ricca E. Matrix Production, Pigment Synthesis, and Sporulation in a Marine Isolated Strain of Bacillus pumilus. Mar Drugs. 2015;13(10):6472-88. https://doi. org/10.3390/md13106472.

12. Esposito S, Guerriero G, Vona V, Di Martino V, Carfagna S, Rigano C. Glutamate synthase activities and protein changes in relation to nitrogen nutrition in barley: the dependence on different plastidic glucose-6P dehydrogenase isoforms. J Exp Bot. 2005;56:55-64. https://doi.org/10. 1093/jxb/erio06.

13. Glaser P, Frangeul L, Buchrieser C, Rusniok C, Amend A, Baquero F, Berche $\mathrm{P}$, Bloecker $\mathrm{H}$, Brandt $\mathrm{P}$, Chakraborty T, Charbit A, Chetouani F, Couvè E, De Daruvar A, Dehoux P, Domann E, Dominguez-Bernal G, Duchaud E, Durant L, Dusserget O, Entian D, Fsihi H, Garcia-Del Portillo F, Garrido P, Gautier L, Goelbel W, Gòmez-LopezN, Hain T, HaufJ, Jackson D, Jones LM, Kaerst U, Kreft J, Kuhn M, Kurapkat G, Madueno E, Maitournam A, Mata Vicente J, Ng E, Nedjari H, Nordsiek G, Novella S, De Pablos B, PèrezDiaz J-C, Purcell R, Remmel B, Rose M, Schlueter T, Simoes N, Tierrez A, Vàzques-Boland JA, Voss H, Wehland J, Cossart P. Comparative Genomics of Listeria Species. Science. 2001;294:849-52. https://doi.org/10.1126/ science. 1063447.

14. Weller D, Andrus A, Wiedmann M, Den Bakker HC. Listeria booriae sp. nov. and Listeria newyorkensis sp. nov., from food processing environments in the USA. Int J System Evol Microbiol 2015;65:286-292. https://doi.org/10. 1099/ijs.0.070839-0

15. Glaser P, Frangeul L, Buchrieser C, Rusniok C, Amend A, Baquero F, et al. Comparative genomics of Listeria species. Science. 2001;294:849-52. https://doi.org/10.1126/science.1063447.

16. Trost M, Wehmhoner D, Karst U, Dieterich G, Wehland J, Jansch L. Comparative proteome analysis of secretory proteins from pathogenic and nonpathogenic Listeria species. Proteomics. 2005;5:1544-57. https://doi. org/10.1002/pmic.200401024.

17. Gerst MM, Somogyi Á, Yang X, Yousef AE. Detection and characterization of a rare two-component lantibiotic, amyloliquecidin GF610 produced by Bacillus velezensis, using a combination of culture, molecular and bioinformatic analyses. J Appl Microbiol. 2021. https://doi.org/10.1111/ jam.15290.

18. Lin LZ, Zheng QW, Wei T, Zhang ZQ, Zhao CF, Zhong H, Xu QY, Lin JF, Guo LQ. Isolation and Characterization of Fengycins Produced by Bacillus amyloliquefaciens JFL21 and Its Broad-Spectrum Antimicrobial Potential Against Multidrug-Resistant Foodborne Pathogens. Front Microbiol. 2020;11:579621. https://doi.org/10.3389/fmicb.2020.579621.

19. Zotta T, Guidone A, Tremonte P, Parente E, Ricciardi A. A comparison of fluorescent stains for the assessment of viability and metabolic activity of lactic acid bacteria. World J Microbiol Biotechnol. 2012;28:919-27. https:// doi.org/10.1007/s11274-011-0889-x.

20. Farkas A, Maroti G, Kereszt A, Kondorosi E. Comparative analysis of the bacterial membrane disruption effect of two natural plant antimicrobial peptides. Front Microbiol. 2017;8:51. https://doi.org/10.3389/fmicb.2017. 00051.

21. Ladha G, Jeevaratnam K. Characterization of purified antimicrobial peptide produced by Pediococcus pentosaceus LRR1, and its application in preservation of white leg shrimps. World J Microbiol Biotechnol. 2020;36:72. https://doi.org/10.1007/s11274-020-02847-w.

22. Gao Z, Van Nostrand JD, Zhou J, Zhong W, Chen K, Guo J. Anti-listeria Activities of Linalool and Its Mechanism Revealed by Comparative Transcriptome Analysis. Front Microbiol. 2019;10:2947. https://doi.org/10. 3389/fmicb.2019.02947.

23. Naclerio G, Ricca E, Sacco M, De Felice M. Antimicrobial activity of a newly identified bacteriocin of Bacillus cereus. Appl Environ Microbiol. 1993;59:4313-6.

24. Hwang S, Shao Q, Williams H, Hilty C, Gao YQ. Methanol Strengthens Hydrogen Bonds and Weakens Hydrophobic Interactions in Proteins - A Combined Molecular Dynamics and NMR study. J Phys Chem B. 2011;115:6653-60. https://doi.org/10.1021/jp111448a.

25. Ferreira WT, Hong HA, Hess M, Adam JRG, Wood H, Bakun K, Baccigalupi L, Ferrari E, Brisson A, Ricca E, Rejas TM, Meijer WJJ, Soloviev M, Cutting SM. Micellar Antibiotics of Bacillus. Pharmaceutics. 2021;13(8):1296. https:// doi.org/10.3390/pharmaceutics13081296.

26. Sumi CD, Yang BW, Yeo I-C, Hahm YT. Antimicrobial peptides of the genus Bacillus:a new era for antibiotics. Can J Microbiol. 2015;61:93-103. https:// doi.org/10.1139/cjm-2014-0613.

27. Finn RD, Clements J, Arndt J, Miller BL, Wheeler F, Schreiber F, Bateman A, Eddy SR. HMMER web server: 2015 update. Nucleic Acids Res. 2015;43:W30-8. https://doi.org/10.1093/nar/gkv397.

28. Aunpad R, Na-Bangchang K. Pumilicin 4, A Novel Bacteriocin with AntiMRSA and Anti-VRE Activity Produced by Newly Isolated Bacteria Bacillus pumilus Strain WAPB4. Curr Microbiol. 2007:55:308-13.

29. Zhaohui W, Chengiun S, Lixia Z, Da G, Ying W, Xiudong X, Xiaoli L, Jjanzhong Z. A novel subtilin-like lantibiotics subtilin JS-4 produced by Bacillus subtilis JS-4, and its antibacterial mechanism against. Listeria monocytogenes Food Sci Technol. 2021;142:110993.

30. Zhao X, Kuipers OP. Identification and classification of known and putative antimicrobial compounds produced by a wide variety of Bacillales species. BMC Genomics. 2016;17:882. https://doi.org/10.1186/ s12864-016-3224-y.

31. Molohon KJ, Blair PM, Park S, Doroghazi JR, Maxson T, Hershfield JR, Flatt $\mathrm{KM}$, Schroeder NE, Ha T, Mitchell DA. Plantazolicin is an ultra-narrow spectrum antibiotic that targets the Bacillus anthracis membrane. ACS Infect Dis. 2016; 2(3): 207-220. doi: 10.1021/acsinfecdis.5b00115.

32. Benov L. Effect of growth media on the MTT colorimetric assay in bacteria. PLoS One. 2019;14(8):e0219713. https://doi.org/10.1371/journal.pone. 0219713.

\section{Publisher's Note}

Springer Nature remains neutral with regard to jurisdictional claims in published maps and institutional affiliations.

Ready to submit your research? Choose BMC and benefit from:

- fast, convenient online submission

- thorough peer review by experienced researchers in your field

- rapid publication on acceptance

- support for research data, including large and complex data types

- gold Open Access which fosters wider collaboration and increased citations

- maximum visibility for your research: over $100 \mathrm{M}$ website views per year

At BMC, research is always in progress.

Learn more biomedcentral.com/submissions 